\title{
Using palaeoecology to explore the resilience of southern African savannas
}

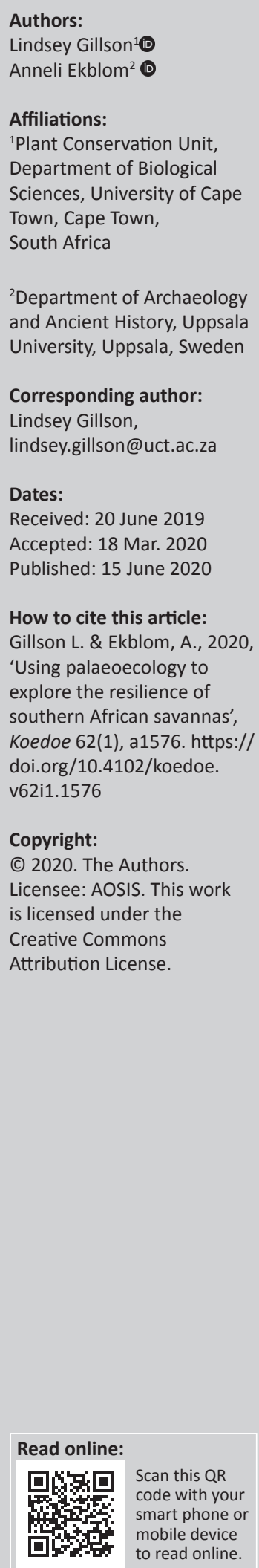

Savannas are dynamic and heterogeneous environments with highly variable vegetation that responds to a multitude of interacting drivers. Rainfall, soils, herbivory, fire and land use all effect land cover in savannas. In addition, savannas have a long history of human use. Setting management goals is therefore complex. Understanding long-term variability in savannas using palaeoecology provides a context for interpretation of recent changes in vegetation and can help to inform management based on acceptable or historical ranges of variability. In this article, we review and synthesise palaeoecological data from southern African savannas and use resilience theory as a framework for structuring and understanding of vegetation dynamics in savannas. We identify thresholds between alternate stable states, which have different ecological properties, suites of species and ecosystem services. Multi-proxy palaeoecological records can assist in identifying alternate states in savanna vegetation, as well as showing how different drivers (fire, herbivory, nutrients and climate) interact to drive transitions between states.

Conservation implications: The ecological thresholds identified from palaeoecological data can be used to inform the development of management thresholds, known as thresholds of potential concern. Thresholds of potential concern are designed to facilitate or impede transitions between states by manipulation of those variables (e.g. fire and herbivory) that can be controlled at the landscape scale.

Keywords: resilience; thresholds; thresholds of potential concern; palaeoecology; alternate stable states.

\section{Introduction}

In savannas, interactions between fire, herbivory and climate can alter ecosystem structure and function, potentially resulting in shifts between grass- and tree-dominated states (Hempson et al. 2019; Sankaran, Ratnam \& Hanan 2008). These transitions may occur on any spatial scale from local (hundreds of metres) to regional (subcontinental) and timescales of decades to centuries. The heterogeneity and dynamism of savanna vegetation and the complexity of drivers and scales raise challenges both theoretically and practically, especially in view of climate change and possible vegetation responses. Resilience theory provides a framework for integrating the knowledge of savanna dynamics that can be applied in biodiversity conservation and ecosystem management, as will be explored in this article. Two aspects of resilience are commonly described in the literature: (1) ecological resilience - which is defined as the capacity of an ecosystem to withstand disturbance without changing structure and function and (2) engineering resilience - which is defined as the capacity of an ecosystem to recover from a disturbance that causes change in structure and function (Holling 1996; Oliver et al. 2015; Sundstrom et al. 2016).

Understanding of Holocene vegetation dynamics can elucidate how interactions between fire, herbivory and climate alter ecosystem structure and function over different timescales (Venter, Hawkins \& Cramer 2017) - knowledge that is fundamental for the formulation of management strategies today and in the future. In addition, studies of areas with different management histories illustrate possible effects of different combinations of fire and herbivory over time. Here we will focus on palaeoecological sequences from three protected areas - Kruger National Park (KNP) and Hluhlwe-iMFolozi Parks (HiP) in South Africa and Limpopo National Park (PNL) in Mozambique - to analyse how different drivers (e.g. fire, herbivory, nutrients and climate) interact to drive transitions between alternate states in savanna vegetation.

The focus on protected areas is motivated by the specific challenges of conservation management, in defining the range of variability that can sustain biodiversity without leading to irreversible or 
undesirable shifts in vegetation with changing environmental parameters (Rogers 2003). Non-equilibrium ecology and resilience thinking have led to innovations in savanna management and conservation, with the emergence of thresholds of potential concern (TPCs) as operational goals that define the upper and lower limits of acceptable change in ecosystem parameters (Rogers 1997, 2003; Rogers \& O'Keeffe 2003). The formulation of TPCs in defining spatiotemporal heterogeneity raises both ecological and social questions (Biggs et al. 2011). Most of Africa's parks and protected areas were founded under atypical conditions that nevertheless continue to shape expectations to this day. Hunting of large herbivores and carnivores, as well as policies of fire suppression and outbreaks of disease such as rinderpest during the 18th-19th century, likely transformed ecosystem structure and function, yet we have limited knowledge of how ecosystems looked prior to this time. Stakeholder preferences are informed also by how they perceive current changes in ecosystem state relative to their own personal baselines. We have argued elsewhere (Forbes et al. 2018) that baselines shift depending on personal experience and the lifespan of projects, and highlight the valuable role of long-term data in contextualising change that has occurred over recent decades. Palaeoecological data may therefore help managers and ecologists to envisage scenarios to help that are outside of their personal experience (Gillson \& Marchant 2014; Gillson 2015a).

In this article, we interpret changes in vegetation structure inferred from palaeoecological data in terms of resilience and thresholds, and attempt to identify the range of factors that drive transitions between alternate stable states, or which promote resistance and stability of vegetation, despite environmental variability. To translate the palaeoecological data into a form that can be utilised in ecosystem management, we then compare long-term (palaeo) ecological thresholds with management thresholds (TPCs). We anticipate that such a framework could inform future quantitative analysis and modelling that could allow savanna managers and conservationists to explore the effects of manipulating fire and herbivory under various scenarios of future rainfall, temperature and carbon dioxide $\left(\mathrm{CO}_{2}\right)$.

\section{Methods}

The basis for our discussion is data generated from multiple palaeoecological records from KNP and HiP in South Africa, and Limpopo National Park in Mozambique (PNL [see Figure 1 and Table 1-A1]) (Ekblom \& Gillson 2010a, 2010b, 2010c; Ekblom, Gillson \& Notelid 2011; Ekblom et al. 2012; Gillson 2015b; Gillson \& Duffin 2007; Gillson \& Ekblom 2009, $2009 \mathrm{~b})$. The period discussed here, the last ca. 6000 years, has experienced both periods of warming and cooling combined with shifts in rainfall (Scott 2016; Scott et al. 2012). The time period covers the end of the mid-Holocene warming 4000 years ago when there was an increase in rainfall in the summer rainfall region. This was followed by a period of variable but overall cooler and drier conditions. Overall wetter conditions took place ca. $1200-800$ years ago associated with globally

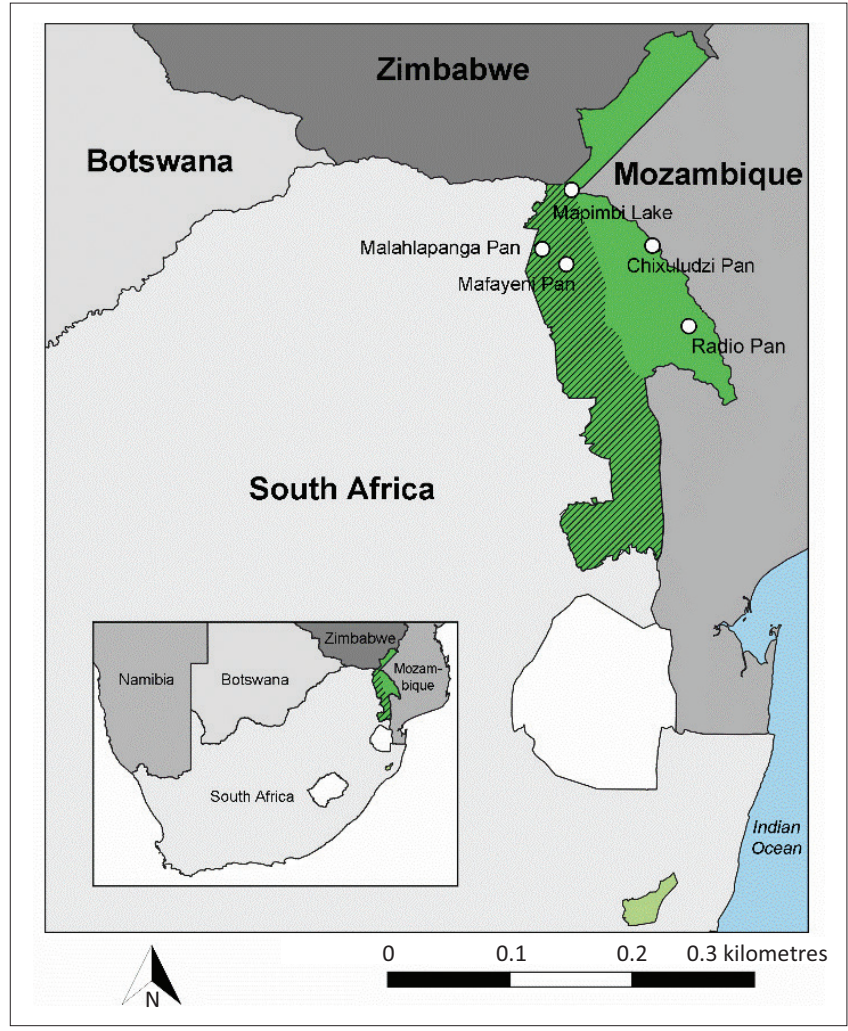

FIGURE 1: Map showing location of sediment cores and protected areas mentioned in the text.

warmer climate (sometimes referred to as the medieval warming) (Holmgren et al. 2003; Humphries, Green \& Finch 2016; Lee-Thorp et al. 2001; Neumann, Botha \& Scott 2014; Scott \& Lee-Thorp 2004; Scott et al. 2012; Scott 2016). Shorter cool-dry events took place in AD 1100, 1350, 1450 and 1500 interspersed with periods of higher rainfall. A prolonged trend of cool-dry conditions took place after AD 1600, especially severe at AD 1700, with a return of more rainfall only 200 years ago (Holmgren et al. 2003, 2012; Lee-Thorp et al. 2001; Scott et al. 2012; Sundqvist et al. 2013; Woodborne et al. 2015, 2016). Although the dynamics of these changes, and if these climate shifts are analogous to future climate shifts, are still debated (Fitchett et al. 2017), the knowledge of the scale and rate of vegetation changes are important to understand for informed management decisions.

Changes in vegetation are here reconstructed using the relative changes of pollen types in dated sediments. Transitions from grass-dominated to woody vegetation are studied using pollen from sediments and stable carbon isotopes in soil profiles. The pollen record is compared with the amount of charcoal as an indicator of fire frequency/intensity and dung loving spores as a possible indicator of herbivore abundance, while nitrogen availability is also reconstructed based on $\delta^{15} \mathrm{~N}$ isotopes. Transitions from grass-dominated to woody vegetation can also be studied using stable carbon isotopes in soil profiles. Grasses and trees in savannas use different photosynthetic pathways, resulting in distinctive isotopic signatures, where grasses are enriched in heavier carbon. By analysing $\delta^{13} \mathrm{C}$ in soil profiles, changes in the relative abundance of grasses and trees over time can be estimated, 
with more recent vegetation reflected in the uppermost soil or sediment profiles. Although the palaeoecological records from small wetlands, pans and swamps presented here reflect local changes, and sampling has been limited by suitable sediment deposits and available proxies, we are still able to construct a general understanding of vegetation dynamic in terms of the factors that might drive transitions between stable states, or that promote resistance or resilience.

\section{Ethical considerations}

This article followed all ethical standards for a research without direct contact with human or animal subjects.

\section{Results: Alternate stable states in Savannas \\ Water-limited grassland}

The most stable vegetation states identified in our pollen records are water-limited grasslands. Although annual rainfall (600 mm/year) is presently sufficient for supporting a more dense woody cover, trees are scarce or absent because of water limitations imposed by local hydrology (i.e. lack of connection to ground water fed by perennial rivers). Such a landscape is exemplified by Radio Pan in PNL (Ekblom \& Gillson 2010c). The resistance or resilience of this vegetation state is demonstrated by the lack of response of tree cover (represented by arboreal pollen) to climate, fire and nutrients. On the basis of the time series data, we did simple regression analyses between tree cover, charcoal (fire influence), dung loving spores (possible grazing influence) and $\delta^{15} \mathrm{~N}$ isotopes (nitrogen availability). We expected arboreal pollen abundance to have a significant negative relationship with spores and charcoal, reflecting the negative impact of herbivory and fire on tree recruitment. We expected to find a positive correlation between nitrogen availability and tree abundance, reflecting a positive relationship between tree abundance and nitrogen. However, at Radio Pan, there was no significant correlation between arboreal pollen and nitrogen availability (based on $\delta^{15} \mathrm{~N}$ ), fire (based on charcoal abundance) or herbivory (based on dung fungal spore abundance) (Figure 2a) (Ekblom \& Gillson 2010c). In contrast, a nearby site, Chixuludzi, with connections to perennial water, that is, Limpopo River, showed significant correlations between tree abundance, fire and nitrogen availability (Figure 2b) (Ekblom \& Gillson 2010c).

The complete dominance of grassland surrounding Radio Pan persisted throughout a 600-year history, despite changes in rainfall and in contrast to Chixuludzi, which showed variations in tree cover over time (Figures $2 a$ and $2 b$ ). We suggest that at Radio Pan, water is the limiting factor that constrains tree recruitment, meaning that changes in fire and herbivory had no effect on tree abundance. It is not clear from the pollen data whether the resistance of grassland around

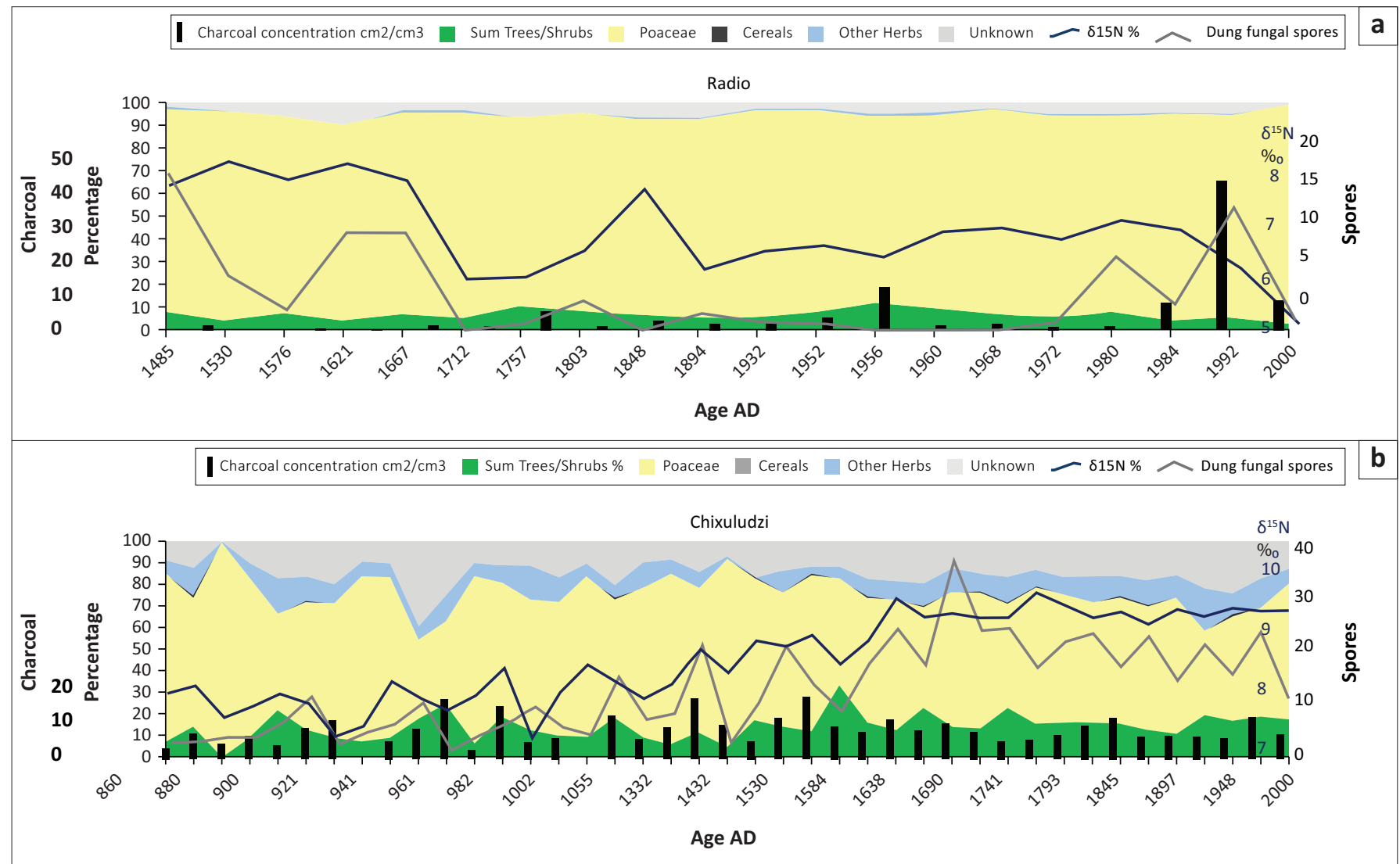

FIGURE 2: Summary diagrams of the Radio (a) and Chixuludzi (b) sedimentary sequences. Colored silhouettes show distribution of the main vegetation groups in percentages based on terrestrial pollen (c. 300-500 pollen); Black bars show charcoal concentration (estimated as concentration $\mathrm{cm}^{2} / \mathrm{cm}^{3}$ ). In the Radio diagram (a) the red lines shows the distribution of coprophilous dung fungal spores (converted in percentages in relation to the pollen sum) and the blue lines changes in the $\delta^{15} \mathrm{~N}$ values. The blue line shown in the Chixuludzi diagram (b) shows changes in the $\delta^{15} \mathrm{~N}$ values and the grey line the distribution of coprophilous dung fungal spores (converted in percentages in relation to the pollen sum). 
Radio Pan is conferred by persistence of grassland composition or by internal dynamism (i.e. turnover of grass species within the grass community). Recent work from highland grasslands Mpumalanga (Breman et al. 2019), based on phytoliths, suggests that resilience of grasslands might be enhanced through internal turnover within the grassland community, which can buffer the effects of changing climate, thereby enhancing resistance. Further analysis of phytoliths and biomarkers from water-limited grasslands such as Radio Pan might help to resolve this question.

\section{Herbivore-limited grassland (grazing lawn) transitioning to wooded savanna}

Grazing lawns are maintained by high levels of herbivory, especially by mega-herbivores such as white rhino, which limit tree recruitment and also prevent fire by reducing grass biomass levels below those which can support fire (Waldram, Bond \& Stock 2007). Herbivores can contribute to fast nutrient cycling through addition of faeces and urine to the soil, although they may also promote competition for nitrogen by removal of biomass. Competition for nitrogen can also help maintain grazing lawns as grasses grow quickly and the rapid uptake of nitrogen makes them the superior competitor, able to exclude trees. These grazing lawns can persist over long time periods but might be de-stabilised by sudden losses of herbivory (e.g. because of drought, disease or overhunting) (Staver \& Bond 2014; Waldram et al. 2007).

Decreased herbivory in combination with increased water availability could therefore facilitate transitions from grazing lawns to wooded (open-canopy) savannas, especially if increased water in the landscape allowed dispersal of waterdependent herbivores, reducing pressure on vegetation around water sources (Redfern et al. 2005). We observed this phenomenon in the pollen record from Malahlapanga (KNP), our oldest record covering a long period of climate variability. Here, an open grassland (indicated by very scarce tree pollen and absence of charcoal abundance) transitioned to fire-prone wooded savanna during the period of increasing rainfall around 800 years ago (Figure 3a) (Gillson \& Ekblom 2009a).

As mega-herbivores such as rhino continue to decline in African savannas because of illegal hunting (Bennett 2014; Lubbe et al. 2017; Wittemyer et al. 2014), we might expect the number of grazing lawns to decrease (Archibald et al. 2005; Waldram et al. 2007). Beyond a threshold of woody plant density, densely wooded areas may also create barriers for fire by shading out grass biomass and creating discontinuities in the fuel layer, which would further enhance recruitment of woody taxa (Higgins \& Scheiter 2012). If the atmospheric forcing resulting from global warming is analogous to the past, we would expect more rainfall with higher temperatures. However, current climate models suggest overall drier conditions with higher incidence of extreme rainfall events (Engelbrecht, Engelbrecht \& Dyson 2013; Engelbrecht, McGregor \& Engelbrecht 2009; Pinto, Jack \& Hewitson 2018) and/or more unpredictability (Haensler 2010; Haensler, Hagemann \& Jacob 2011a; Pinto et al. 2016). Regardless of rainfall changes, the added effects of $\mathrm{CO}_{2}$ fertilisation (see below) might further enhance the competitiveness of trees, shifting the balance away from open grassland habitats (Bond \& Midgley 2012).

\section{Unstable wooded savannas}

The above examples are savannas where open grass cover is persistent as trees are constrained either by water availability, herbivory and/or nitrogen availability. Below we will describe savannas that are potentially unstable and that can change from open grassland to wooded savanna because of one or the combination of drivers. On a landscape scale, savannas are constituted by patches of dense or lightly wooded areas interspersed with grasslands. Overall, the stability of grass or woody cover is maintained when the number of dense and lightly wooded patches remains constant at the landscape scale, although each patch will go through asynchronous cycles of tree recruitment, thickening and senescence, a process known as patch dynamics (see Gillson 2004a). However, drivers such as dramatic, region-wide changes in herbivore density might lead to mass tree recruitment, as occurred at the end of the 19th century during the rinderpest pandemic (Staver \& Bond 2014). Furthermore, policies of fire suppression might also facilitate tree recruitment, as was the case with the fire suppression policy implemented in South Africa during the early 20th century (e.g. Carruthers 1995; Van Wilgen et al. 2004). In both of these examples, the decline in herbivory and fire suppression resulted in a mass recruitment of woody cover, which led to an overall loss of patch structure through the development of even-aged tree or shrub stands. The increase in woody cover could limit the effects of fire by creating discontinuity in the fuel (grass biomass) layer, further enhancing the possibilities for woody recruitment.

We see evidence for mass closure of savanna tree canopies, for example, in stable isotope data from soil profiles in HiP, where $\delta^{13} \mathrm{C}$ consistently decreases in the upper layers of the soil profile, indicating a transition from mixed $\mathrm{C}_{3}-\mathrm{C}_{4}$ vegetation to $\mathrm{C}_{3}$-dominated vegetation over time (Gillson 2015b). Furthermore, when the frequency distribution of $\delta^{13} \mathrm{C}$ is analysed, the stable isotope data show some evidence of bimodal distribution, clustered around $\delta^{13} \mathrm{C}$ values typical of grasses and trees. This bimodality is a possible signature of transition between alternate stable states; if woody cover was a continuum between more and less grassy landscapes, we would expect the stable isotope data to be normally distributed and not bimodally distributed as here (Gillson 2015b). Similarly, analysis of aerial photographs covering the period from the 1930s to the 21st century shows consistent increase in tree canopy cover across different landuse types that differ in grazing and fire management history (conservation area, communally managed farm and commercial farm), providing evidence for a global rather than a local driver (Wigley, Bond \& Hoffman 2009, 2010).

\section{Wooded savanna transitioning to closed canopy forest}

While savanna trees are able to persist in fire-prone environments through re-seeding or re-sprouting, forest trees 
cannot tolerate fire. Closure of tree canopies in savannas will shade out the herbaceous layer, potentially excluding fire and allowing fire-sensitive, shade-tolerant forest trees to penetrate (Charles-Dominique et al. 2015; Higgins \& Scheiter 2012; Hoffmann et al. 2012). Once these trees have established, they would eventually replace the shade-intolerant savanna species and would continue to exclude fire through shading out of the herbaceous layer. This feedback between vegetation and fire exclusion will continuously promote forest trees and associated taxa into an alternate stable state (see Figure 5). Because perennial rivers in savannas are typically bordered by riverine forests, and patches of true forest can co-exist alongside wooded savanna, we might expect the closure of tree canopies in savannas to lead to transitions to forest vegetation that are difficult to reverse. Such a hysteretic mechanism has been modelled using an adaptive dynamic global vegetation model (aDGVM) and is predicted to lead to an expansion of forest biomes at the expense of savanna and grassland biomes by 2100 (Higgins \& Scheiter 2012).

Forest transitions would be difficult to reverse because forest ecosystems maintain themselves through the feedback mechanism of shading and fire exclusion, as described above (Staver, Archibald \& Levin 2011). A transition back to open savanna might be expected only in the case of severe firestorms, which are rare events where intense fires spread to the forest canopy (Archibald et al. 2017; Charles-Dominique et al. 2015). Another situation is in case of very extreme and prolonged or repeated droughts which may kill off trees. At Mapimbi, in the extreme north of KNP, forest taxa declined during the 18th century, which has been connected with the extreme droughts in this period (Figure 3b) (Ekblom et al. 2012; Holmgren et al. 2003, 2012; Lee-Thorp et al. 2001; Scott et al. 2012; Sundqvist et al. 2013; Woodborne et al. 2015, 2016). An analogous situation is where humans clear patches of forest, for example, for crop cultivation, which may interact with drought effects; however, there is little evidence of historical forest clearing on a larger scale (Ekblom et al. 2012; Gillson \& Ekblom 2009b). Riverine forest recovered within a century from these climatically induced disturbances. Riverine forest also showed relatively rapid recovery over a few decades following the extreme flood events in the 20th century (O'Connor 2010; Rountree, Rogers \& Heritage 2000). Even though riverine forests in Mapimbi recovered, the centennial scale of recovery from droughts is problematic from a managerial point of view and may have far reaching consequences that are difficult to predict because of the uncertainty in the climate model projections. Again, negative effects on forest vegetation from more droughts or more catastrophic events may be countered by $\mathrm{CO}_{2}$ fertilisation, but more data are needed to assess this.

\section{Discussion and Conclusions: Implications for ecosystem services and management options}

The palaeoecological record shows evidence of different alternate stable states and mechanisms of resilience and resistance in the vegetation of southern African savannas (Figure 4a). The most resistant form of vegetation that we encountered in our data is water-scarce open grasslands. These are maintained by a combination of local hydrology and fire despite climate variability. Water scarcity overrides other factors such as fire, herbivory and nutrients (Beckage et al. 2019) that we would normally expect to correlate with tree abundance in landscapes that are less water limited (e.g. see Gillson \& Ekblom 2009a). The effects of global warming on rainfall patterns currently are debated (Fitchett et al. 2017) and there is no consensus here other than that conditions will become more unpredictable (see above). Thus, we will leave open the question of effects of rainfall changes to look at other dynamics in this discussion. However, the managerial decisions discussed below will be relevant also for observed effects of rainfall changes.

Grazing lawns are open habitats similar to water-scarce grasslands, but they are maintained by mega-herbivores, particularly white rhino. Their continued existence will therefore be threatened by the ongoing illegal killing of rhino (Lubbe et al. 2017; Waldram et al. 2007). The loss of open, grassy landscapes has implications for grazers and other flora and fauna adapted to these environments (Higgins \& Scheiter 2012; Parr et al. 2014). Reduction in open grazing lawns may also be detrimental to wildlife tourism as it will decrease game viewing potential. Management would need to focus on monitoring of open areas, through on the ground and remotely sensed data, and rapid management action where tree encroachment reaches a TPC (Gillson \& Duffin 2007; Rogers \& Biggs 1999) (Figure 4b). For example, intense fires have been shown to effectively control shrub encroachment (Van Wilgen et al. 2014) and could be used alongside increased herbivore density in an attempt to curb tree recruitment. Furthermore, the capacity to support mega-herbivores may increase under conditions of high $\mathrm{CO}_{2}$ (Scheiter \& Higgins 2012).

The most variable and unstable type of vegetation that we found in the palaeoecological record is the wooded, heterogeneous savannas that typify most of the savanna biome. These landscapes can exist in a multitude of forms with varying levels of tree cover (e.g. see Sankaran et al. 2005, 2008). From a conservation management perspective, there are many ecologically possible options, and decisions about the desirable state of these landscapes will have different trade-offs, for example, between carbon storage and game viewing and/or grazing mentioned above. Decisions will therefore need to consider the perspectives of multiple stakeholder groups (Biggs et al. 2011). In this context, it is also important to consider the landscape history of individual sites and the acceptance of landscape transformation (Gillson 2015a; Gillson \& Marchant 2014). Woody plant thickening may be seen as undesirable in ancient grassland sites (Parr et al. 2014), but may be tolerated in sites that have been historically cleared but which are recovering because of changing land uses, for example, land abandonment. Therefore, site-specific TPCs would be needed, where stakeholders decide on the acceptable limits of change in woody cover, depending on the landscape history and their land-use needs. 


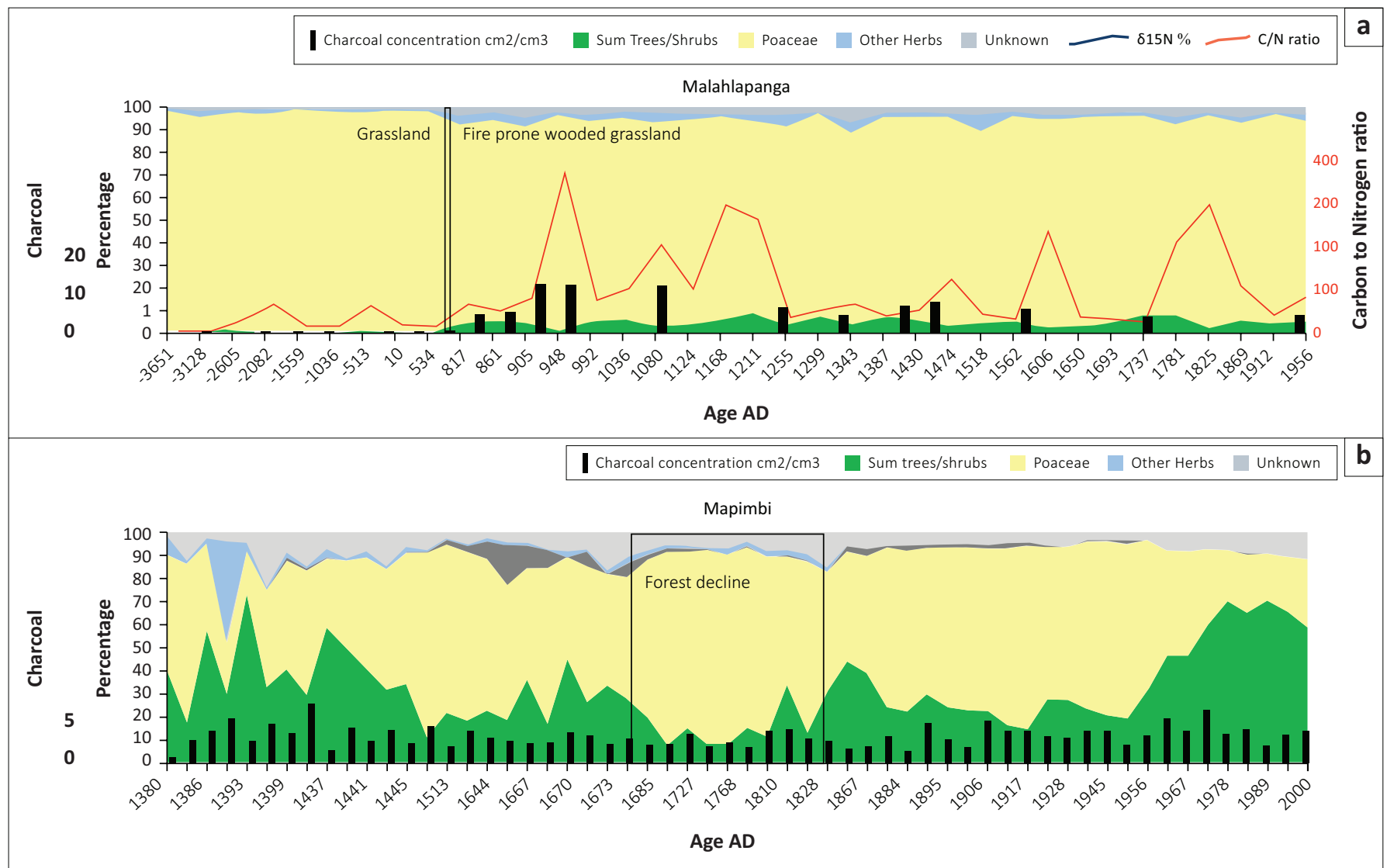

FIGURE 3: Summary diagrams of the Malahlapanga (a) and the Mapimbi (b) sedimentary sequences. Colored silhouettes show distribution of the main vegetation groups in percentages based on terrestrial pollen (c. 300-500 pollen); Black bars show charcoal concentration (estimated as concentration $\mathrm{cm}^{2} / \mathrm{cm}^{3}$ ). The blue lines in the Malahlapanga sequence (a) show the $\delta^{15} \mathrm{~N}$ values and the red lines the $\mathrm{C} / \mathrm{N}$ (eg. Carbon to Nitrogen) ratio.

The degree of change in vegetation cover in savannas over decadal to millennial timescales is poorly understood. Yet, in deciding management thresholds, it is important to understand how the vegetation cover has changed before, during and after the main environmental and historical events that have shaped the southern African region since the mid-Holocene. These include changes in human land use, including the arrival of pastoralists from ca. 2000 years ago and increased management of fire, as also warmer conditions of the Mediaeval Warm period, the Little Ice Age. More recent changes that may have influenced vegetation changes are the growth of the international trade in ivory as well as the rise of the use of firearms in hunting for sport and trade, colonial settlement and associated changes in faunal assemblages (e.g. extermination of predators, local extirpation of elephants) and land management (e.g. replacement of traditional fire management with policies of fire suppression) (Carruthers 1995; Holmgren et al. 2001, 2003, Van Wilgen et al. 2004). In addition to this, there are 20th-century changes in warming temperatures, changing rainfall patterns, $\mathrm{CO}_{2}$ fertilisation, which interact with the effects of past and present land-use changes, including the effects of urbanisation, land abandonment and the growth of the private conservation sector. By examining the historical range of variability under different climatic and land-use scenarios, stakeholders can decide on the acceptable range of variability and thereby better define the TPCs in tree cover, which is appropriate to their local context (Figure 4b) (Biggs et al. 2011; Gillson \& Duffin 2007).
In the future, the resistance of these landscapes might be compromised by the effects of $\mathrm{CO}_{2}$ fertilisation, which will increase the growth rates of trees, allowing more rapid access to water in deep soil layers and enhancing the water use efficiency of $\mathrm{C}_{3}$ savanna trees to the detriment of the grasses (Bond \& Midgley 2012; Midgley \& Bond 2015). From the mid20th century, increasing $\mathrm{CO}_{2}$ has had a fertilising effect on savanna trees, causing them to grow more rapidly, making them (1) less vulnerable to drought, as roots reach moist soil layers more quickly and (2) more able to escape the fire trap that is, they can quickly reach a height that is higher than the flame zone, allowing them to recruit to larger size classes (Midgley \& Bond 2015). In the absence of $\mathrm{CO}_{2}$ fertilisation, savanna tree seedlings can become trapped in the herbaceous layer, being repeatedly burned to the ground and re-sprouting only from their root stock (Bond \& Midgley 2012). With faster growth under higher $\mathrm{CO}_{2}$ conditions, trees can grow more rapidly, escape the fire trap and join the ranks of adult tree classes (Midgley \& Bond 2015). This effect is currently being exacerbated by escalating illegal hunting of mega-herbivores, historically important in keeping tree canopies open (Bennett 2014; Lubbe et al. 2017; Wittemyer et al. 2014).

Riverine forest responds to changing climatic and disturbance drivers but, as suggested from the Mapimbi record discussed above, recovers from disturbance over decades (e.g. Ekblom et al. 2012; Gillson \& Ekblom 2009b). Although more records are needed to analyse this process in detail, similar 


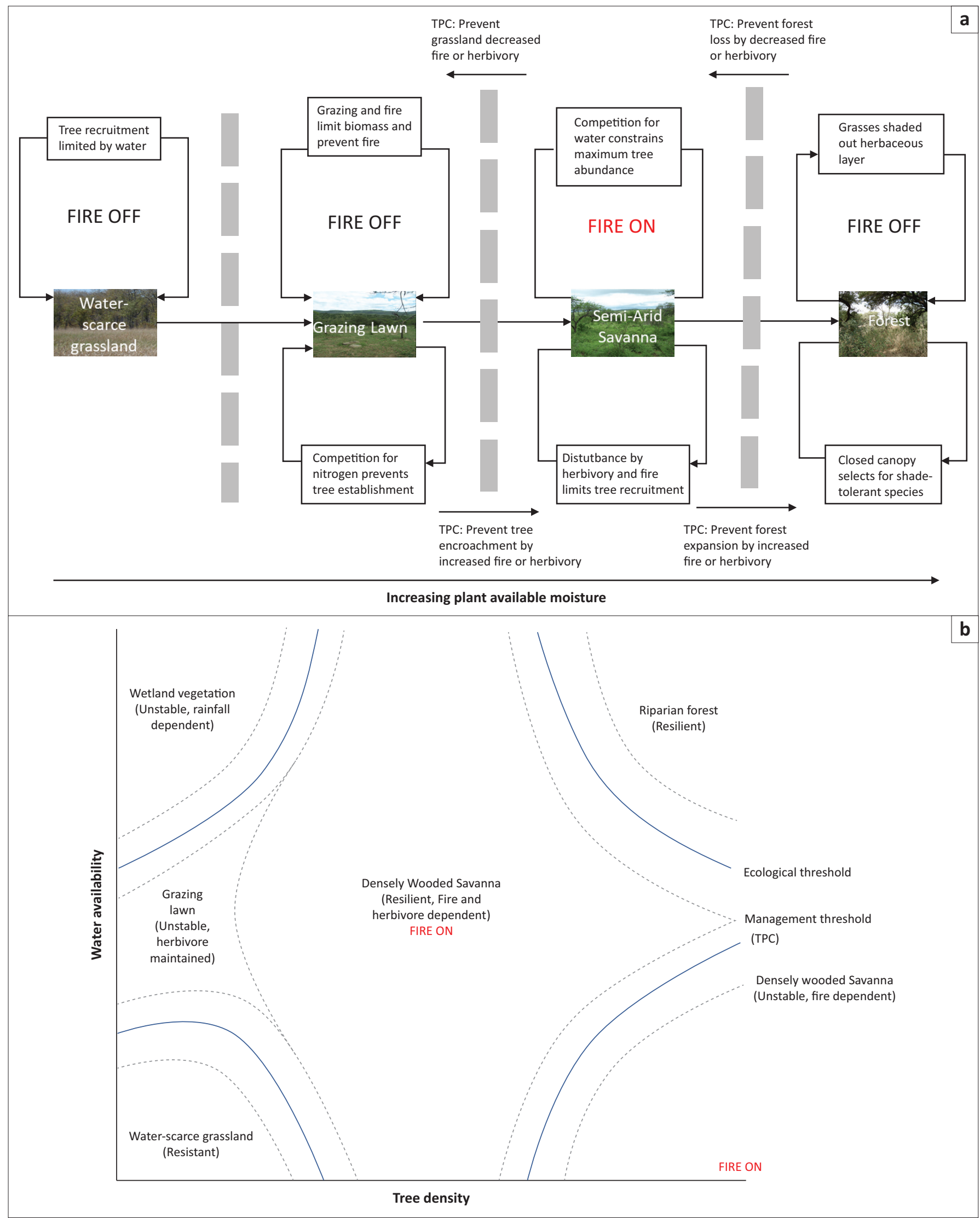

Source: Photos courtesy of A. Ekblom; Purdon, Parr \& Somers 2019

FIGURE 4: (a) Hypothetical model showing transitions between alternate states with increasing plant available moisture, showing the role of vegetation-fire feedbacks in maintaining alternate stable states. (b) Alternate stable states in savanna landscapes as a function of tree density and water availability, indicating both ecological and management thresholds. Ecological states are bounded by solid lines. Dotted lines represent management thresholds (TPC) where tree density could be manipulated through changes in fire or ivory. Three grassland states are possible, depending on levels of water availability. They could transition to fire-maintained wooded savannas if water availability increased and/or herbivory decreased. Wooded savannas could transition to forest ecosystems if canopies closed leading to the exclusion of fire. Management intervention in the form of manipulation of fire and herbivory could be triggered when ecosystems reach the TPC. 
observations have been made in connection recovery of riverine forest after the 20th-century flood events as discussed above. This resilience is likely to be further enhanced by $\mathrm{CO}_{2}$ fertilisation, which will facilitate rapid colonisation by trees. These gallery forests and other forest patches could act as a reservoir of forest species that could colonise closed canopy savannas, leading to hysteretic transitions to forest cover, as predicted by Higgins and Scheiter (2012) (Figure 5). However, the effects of increasingly severe drought and/or more seasonal rainfall (Davis-Reddy \& Vincent 2017; Engelbrecht \& Engelbrecht 2016; Haensler, Hagemann \& Jacob 2011b; Pinto et al. 2016) might act in opposition by hampering the recolonisation of fire- and drought-sensitive forest taxa. Forest expansion would again lead to loss of grazing adapted suites of species, loss of grazing resources and game-viewing activities. Remotely sensed data will be critical in monitoring forest expansion, but more detailed palaeoecological studies assessing rate of change in forest communities will be needed to put recent changes into context. Decisions as to whether this transition should be permitted or prevented must be negotiated based on the trade-offs between ecosystem services, such as carbon storage, grazing, game viewing and biodiversity (Biggs et al. 2011). In this respect, it is important that carbon storage potential of open ecosystems is not underestimated (Veldman et al. 2019) and that the urgent need to increase carbon storage does not overwhelm other concerns such as the biodiversity and ecosystems services provided by open ecosystems (Midgley 2018). Therefore, where the extent of riverine forests is changing, site-specific TPCs will be needed depending on what is ecologically possible and socially preferable.

Transitions between stable states have consequences for biodiversity and the provision of ecosystem services (e.g. see Figure 4). Savanna vegetation responds to a range of factors that operate over a range of spatial and temporal scales, and their heterogeneous and patchy nature means that local-scale changes may not reflect overall vegetation dynamics at landscape or regional scales (e.g. see Gillson 2004a, Ekblom \& Gillson 2009; 2010c). Although global drivers such as $\mathrm{CO}_{2}$ and regional effects such as rinderpest have had major effects on the composition of southern African savannas, the palaeoecological record also shows the importance of local factors, specifically fire and herbivory, in maintaining

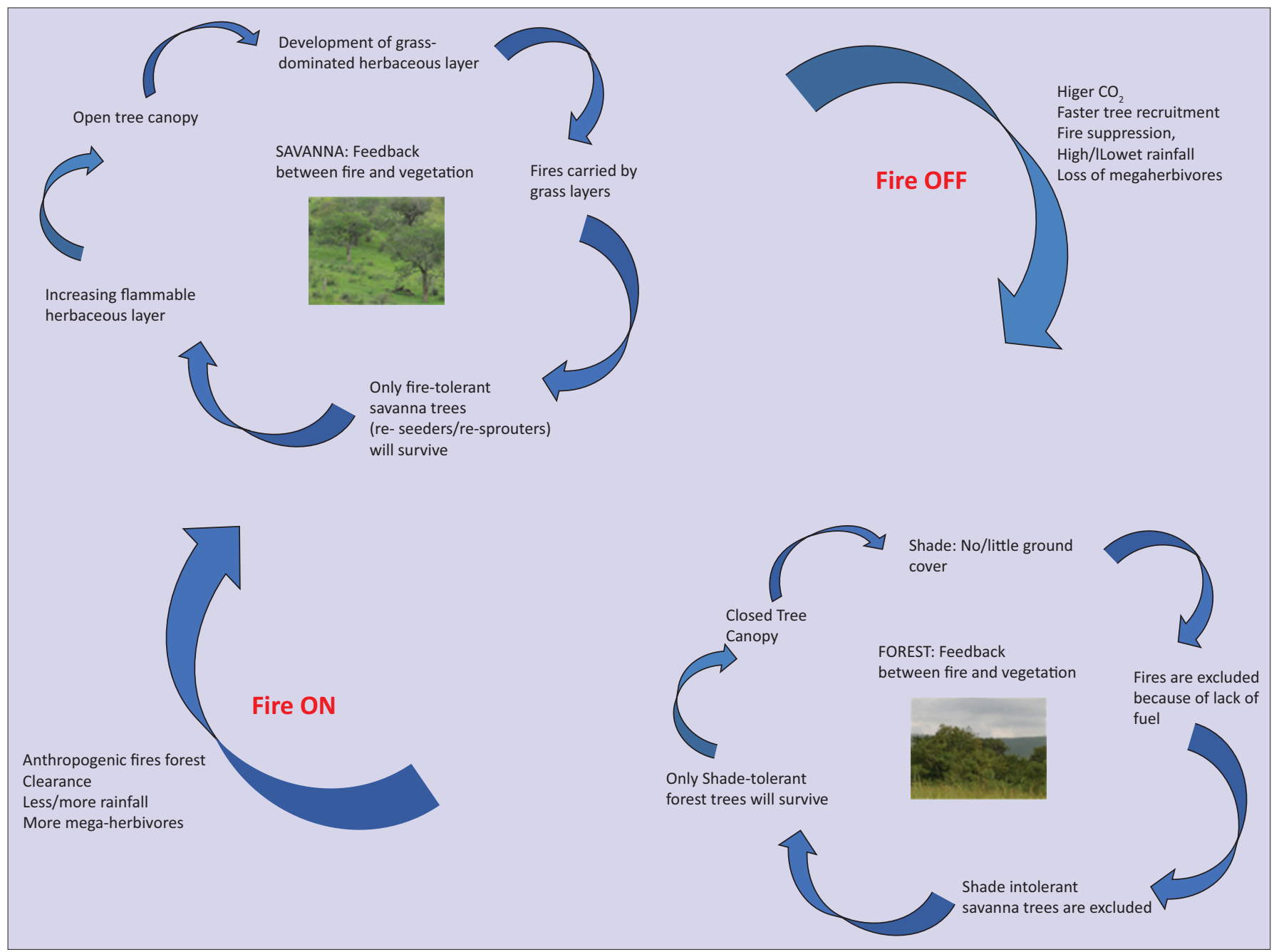

FIGURE 5: Possible feedback mechanisms that maintain savanna and forests as alternate stable states. The grass layer in savannas supports fires, perpetuating an open canopy of fire-tolerant savanna trees. Forest trees shade out understory and prevent fires, perpetuating the recruitment of shade-tolerant, fire-sensitive forest trees. Transitions from savanna to forest can be facilitated by the fertilising effects of $\mathrm{CO}_{2}$, fire suppression, changes in rainfall, loss of megaherbivores, or interactions between any or all of these factors. 
alternate stable states and in driving transitions between them (e.g. Gillson 2004a, 2004b; Gillson \& Ekblom 2009a). This knowledge is of great significance for biodiversity conservation because local factors can be manipulated by conservation managers to maintain desirable states, prevent transitions to undesirable states and even in some cases attempt to reverse transitions. Informed local management can thus have major effects on the future of biodiversity and ecosystem services. Greater understanding of the mechanisms that drive transitions between stable states is needed to identify leverage points where managers can manipulate local drivers, such as fire and herbivory, to develop appropriate TPCs and maintain favoured vegetation states. Such analyses could lead to the development of co-designed models that allow managers to test the effects of different fire and herbivory regimes under varying future scenarios of climate and $\mathrm{CO}_{2}$, possibly utilising palaeoecological records from past warm periods such as the Medieval Warm Period and mid-Holocene altithermal to provide clues of how savannas change in warmer climates and linked rainfall changes. As has been briefly discussed here, there is still plenty of work needed to refine climate models using palaeoecological data (see the discussion in Fitchett et al. 2017). The decision as to what constitutes a desirable state is to some extent subjective, and we argue here that the knowledge of palaeoecology and the impacts of interacting environmental and social drivers can help stakeholders to develop TPCs for current use, as well as to explore future scenarios of vegetation change under different scenarios of rainfall, drought, fire and herbivory. The complexity of savanna ecology and the feedbacks between climate, disturbance and vegetation mean that various future states are possible. For example, increasing drought may reduce fire occurrence because of reduced grass biomass (Van Wilgen et al. 2004) and could also reduce the population of herbivores, reducing grazing pressure. Processes such as system dynamics modelling will assist stakeholders in exploring these feedback loops, helping them to make informed decisions about desirable outcomes and the best management practices to achieve them, both now and in the future.

\section{Acknowledgements}

The authors would like to thank Hana Petersen for producing Figure 1. The authors acknowledge the South Africa National Parks for their permission to carry out the research, as well as for the comments by the anonymous reviewers.

\section{Competing interests}

The authors declare that they have no financial or personal relationships that may have inappropriately influenced them in writing this article.

\section{Author's contributions}

Both authors were involved in generating and interpreting data, and in drafting of the manuscript.

\section{Funding information}

The authors acknowledge funding from the Applied Centre for Climate and Earth System Science (ACCESS), the HigginsTrapnell Family Foundation, the Andrew W. Mellon Foundation and the National Research Foundation (NRF) of South Africa.

\section{Data availability statement}

Data sharing is not applicable to this article as no new data were created or analysed in this study.

\section{Disclaimer}

The views and opinions expressed in this article are the authors' own and not an official position of the institution or funder.

\section{References}

Archibald, S., Beckett, H., Bond, W.J., Coetsee, C., Drucer, D.J. \& Staver, C., 2017, '10- Interactions between fire and ecosystem processes', in J. Cromsigt, $S$. Archibald \& N. Owen-Smith (eds.), Conserving Africa's Mega-Diversity in the Anthropocene: The Hluhluwe-iMfolozi Park Story, pp. 233-262, Cambridge Anthropocene: The Hluhluwe-
University Press, Cambridge.

Archibald, S., Bond, W.J., Stock, W.D. \& Fairbanks, D.H.K., 2005, 'Shaping the landscape: Fire-grazer interactions in an African savanna', Ecological Applications 15(1), 96-109. https://doi.org/10.1890/03-5210

Beckage, B., Bucini, G., Gross, L.J., Platt, W.J., Higgins, S.I., Fowler, N.L. et al., 2019, 'Water limitation, fire, and savanna persistence: A conceptual model', in P.F. Scogings \& M. Sankaran (eds.), Savanna woody plants and large herbivores, pp. 643-659, Wiley, Hoboken, NJ.

Bennett, E.L., 2014, 'Legal ivory trade in a corrupt world and its impact on African elephant populations', Conservation Biology 29(1), 54-60. https://doi.org/10.1111/ cobi.12377

Biggs, H., Ferreira, S., Freitag-Ronaldson, S. \& Grant-Biggs, R., 2011, 'Taking stock after a decade: Does the "Thresholds of Potential Concern" concept need a socioecological revamp?', Koedoe 53(2), 60-68. https://doi.org/10.4102/koedoe. v53i2.1002

Bond, W.J. \& Midgley, G.F., 2012, 'Carbon dioxide and the uneasy interactions of trees and savannah grasses', Philosophical Transactions of the Royal Society B 367(1588), 601-612. https://doi.org/10.1098/rstb.2011.0182

Breman, E., Ekblom, A., Gillson, L. \& Norström, E., 2019, 'Phytolith-based environmental reconstruction from an altitudinal gradient in Mpumalanga, South Africa, 10,600 BP-present', Review of Paleobotany and Pal
104-116. https://doi.org/10.1016/j.revpalbo.2019.01.001

Carruthers, J., 1995, The Kruger National Park: A social and poltical history, University of Natal Press, Pietermaritzburg.

Charles-Dominique, T., Staver, A., Midgley, G. \& Bond, W., 2015, 'Functional differentiation of biomes in an African savanna/forest mosaic', South African Journal of Botany 101(2015), 82-90. https://doi.org/10.1016/j.sajb.2015.05.005

Davis-Reddy, C.L. \& Vincent, K., 2017, Climate risk and vulnerability: A handbook for Southern Africa, 2nd edn., CSIR, Pretoria.

Ekblom, A. \& Gillson, L., 2010a, 'Dung fungi as indicators of past herbivore abundance, Kruger and Limpopo National Park', Palaeogeography, Palaeoclimatology, Palaeoecology 296(1-2), 14-27. https://doi.org/10.1016/j.palaeo.2010.06.009

Ekblom, A. \& Gillson, L., 2010b, 'Fire history and fire ecology of Northern Kruger (KNP) and Limpopo National Park (PNL), Southern Africa', The Holocene 20(7), 10631077. https://doi.org/10.1177/0959683610369499

Ekblom, A. \& Gillson, L., 2010c, 'Hierarchy and scale: Testing the long term role of water, grazing and nitrogen in the savanna landscape of Limpopo National Park (Mozambique)', Landscape Ecology 25, 1529-1546.

Ekblom, A., Gillson, L. \& Notelid, M., 2011, 'A historical ecology of the Limpopo and Kruger National Parks and Lower Limpopo Valley', Journal of Archaeology and Ancient History 1(1), 1-29.

Ekblom, A., Gillson, L., Risberg, J., Holmgren, K. \& Chidoub, Z., 2012, 'Rainfall variability and vegetation dynamics of the lower Limpopo Valley, Southern Africa, $500 \mathrm{AD}$ to present', Palaeogeography, Palaeoclimatology, Palaeoecology 363-364(2012), 69-78. https://doi.org/10.1016/j.palaeo.2012.08.015

Engelbrecht, C.J. \& Engelbrecht, F.A., 2016, 'Shifts in Köppen-Geiger climate zones over southern Africa in relation to key global temperature goals', Theoretical and Applied Climatology 123, 247-261. https://doi.org/10.1007/s00704-014-1354-1

Engelbrecht, C.J., Engelbrecht, F.A. \& Dyson, L.L., 2013, 'High-resolution modelprojected changes in mid-tropospheric closed-lows and extreme rainfall events over southern Africa', International Journal of Climatology 33(1), 173-187. https://doi.org/10.1002/joc.3420 
Engelbrecht, F., McGregor, J. \& Engelbrecht, C., 2009, 'Dynamics of the ConformalCubic Atmospheric Model projected climate-change signal over southern Africa', International Journal of Climatology: A Journal of the Royal Meteorological Society 29(7), 1013-1033. https://doi.org/10.1002/joc.1742

Fitchett, J.M., Grab, S.W., Bamford, M.K. \& Mackay, A.W., 2017, 'Late quaternary research in southern Africa: Progress, challenges and future trajectories', Transactions of the Royal Society of South Africa 72(3), 280-293. https://doi.org/ 10.1080/0035919X.2017.1297966

Forbes, C. J., Gillson, L. \& Hoffman, M. T., 2018, 'Shifting baselines in a changing world: Identifying management targets in endangered heathlands of the Cape Floristic Region, South Africa', Anthropocene 22, 81-93. https://doi.org/10.1016/j.ancene. 2018.05.001

Gillson, L., 2004a, 'Evidence of hierarchical patch dynamics in an East African Savanna?', Landscape Ecology 19(2004):883-894. https://doi.org/10.1007/ s10980-004-0248-5

Gillson, L., 2004b, 'Testing non-equilibrium theories in savannas: 1400 years of vegetation change in Tsavo National Park, Kenya', Ecological Complexity 1(4) 281-298. https://doi.org/10.1016/j.ecocom.2004.06.001

Gillson, L., 2015a, Biodiversity conservation and environmental change: Using palaeoecology to manage dynamic landscapes in the Anthropocene, Oxford University Press, Oxford.

Gillson, L., 2015b, 'Evidence of a tipping point in a southern African savanna?', Ecological Complexity 21(2015), 78-86. https://doi.org/10.1016/j.ecocom.2014.12.005

Gillson, L. \& Duffin, K.I., 2007, 'Thresholds of potential concern as benchmarks in the management of African savannahs', Philosophical Transactions of the Royal Society of London Series B-Biological Sciences 362(1478), 309-319. https://doi. org/10.1098/rstb.2006.1988

Gillson, L. \& Ekblom, A., 2009a, 'Resilience and thresholds in Savannas: Nitrogen and fire as drivers and responders of egetation transition', Ecosystems 12(2009), 1189-1203. https://doi.org/10.1007/s10021-009-9284-y

Gillson, L. \& Ekblom, A., 2009b, 'Untangling anthropogenic and climatic influence on riverine forest in the Kruger National Park, South Africa', Vegetation History and Archaeobotany 18(2009), 171-185. https://doi.org/10.1007/s00334-008-0202-6

Gillson, L. \& Marchant, R., 2014, 'From myopia to clarity: Sharpening the focus of ecosystem management through the lens of palaeoecology', Trends in Ecology \& Evolution 29, 317-325. https://doi.org/10.1016/j.tree.2014.03.010

Haensler, A., 2010, How the future climate of the Southern African region might look like: Results of a high resolution regional climate change projection, PIK Report 23, Potsdam-Institut Für Klimafolgenforschung, Potsdam.

Haensler, A., Hagemann, S. \& Jacob, D., 2011a, 'Dynamical downscaling of ERA40 reanalysis data over southern Africa: Added value in the simulation of the seasonal rainfall characteristics', International Journal of Climatology 31(15), 2338-2349. https://doi.org/10.1002/joc.2242

Haensler, A., Hagemann, S. \& Jacob, D., 2011b, 'The role of the simulation setup in a long-term high-resolution climate change projection for the southern African region', Theoretical and Applied Climatology 106(2011), 153-169. https://doi. org/10.1007/s00704-011-0420-1

Hempson, G.P., Archibald, S., Donaldson, J.E. \& Lehmann, C.E., 2019, 'Alternate grassy ecosystem states are determined by palatability-flammability trade-offs', Trends in Ecology \& Evolution 34(4), 286-290. https://doi.org/10.1016/j.tree.2019.01.007

Higgins, S.I. \& Scheiter, S., 2012, 'Atmospheric CO2 forces abrupt vegetation shifts locally, but not globally', Nature 488(2012), 209-212. https://doi.org/10.1038/ nature11238

Hoffmann, W.A., Jaconis, S.A., Mckinley, K.L., Geiger, E.L., Gotsch, S.G. \& Franco, A.C., 2012, 'Fuels or microclimate? Understanding the drivers of fire feedbacks a savanna-forest boundaries', Austral Ecology 37(6), 634-643. https://doi.org/ 10.1111/j.1442-9993.2011.02324.x

Holmgren, K., Lee-Thorp, J.A., Cooper, G.R.J., Lundblad, K., Partridge, T.C., Scott, L. et al., 2003, 'Persistent millenial-scale climatic variability over the past 25,000 years in Southern Africa', Quaternary Science Reviews 22(21-22), 2311-2326. https:// doi.org/10.1016/S0277-3791(03)00204-X

Holling, C.S., 1996, 'Engineering resilience versus ecological resilience', in P. Schulze,(ed.), Engineering within Ecological Constraints, pp. 31-44, National Academy Press, Washington.

Holmgren, K., Moberg, A., Svanered, O. \& Tyson, P.D., 2001, 'A preliminary 3000-year regional temperature reconstruction for South Africa', South African Journal of Science 97(1-2), 49-51.

Holmgren, K., Risberg, J., Freudendahl, J., Achimo, M., Ekblom, A., Mugabe, J. et al., 2012, 'Water-level variations in Lake Nhauhache, Mozambique, during the last 2,300 years', Journal of Paleolimnology 48, 311-322. https://doi.org/10.1007/ s10933-012-9596-3

Humphries, M., Green, A. \& Finch, J., 2016, 'Evidence of El Niño driven desiccation cycles in a shallow estuarine lake: The evolution and fate of Africa's largest estuarine system, Lake St Lucia', Global and Planetary Change 147, 97-105. https://doi.org/10.1016/j.gloplacha.2016.11.002

Lee-Thorp, J., Holmgren, K., Lauritzen, S.E., Linge, H., Moberg, A., Partridge, T. et al , 2001, 'Rapid climate shifts in the southern African interior throughout the mid to late Holocene', Geophysical Research Letters 28(23), 4507-4510. https://doi. late Holocene', Geophysical
org/10.1029/2000GL012728

Lubbe, B.A., Du Preez, E.A., Douglas, A. \& Fairer-Wessels, F., 2017, 'The impact of rhino poaching on tourist experiences and future visitation to National Parks in South Africa', Current Issues in Tourism 22(1), 8-15. https://doi.org/10.1080/136 South Africa, Current Issu
83500.2017 .1343807
Midgley, G., 2018, 'Narrowing pathways to a sustainable future', Science 360(6390) 714-715. https://doi.org/10.1126/science.aat6671

Midgley, G.F. \& Bond, W.J., 2015, 'Future of African terrestrial biodiversity and ecosystems under anthropogenic climate change', Nature Climate Change 5(2015), 823-829. https://doi.org/10.1038/nclimate2753

Neumann, F.H., Botha, G.A. \& Scott, L., 2014, '18,000 years of grassland evolution in the summer rainfall region of South Africa: Evidence from Mahwaqa Mountain, KwaZulu-Natal', Vegetation History and Archaeobotany 23, 665-681. https://doi. org/10.1007/s00334-014-0445-3

O'Connor, T.G., 2010, 'Transformation of riparian forest to woodland in Mapungubwe National Park, South Africa, between 1990 and 2007', Austral Ecology 35(7),778786. https://doi.org/10.1111/j.1442-9993.2009.02084.x

Oliver, T.H., Heard, M.S., Isaac, N.J., Roy, D.B., Procter D., Eigenbrod, F. et al., 2015 'Biodiversity and resilience of ecosystem functions', Trends in Ecology \& Evolution 30, 673-684. https://doi.org/10.1016/j.tree.2015.08.009

Parr, C.L., Lehmann, C.E., Bond, W.J., Hoffmann, W.A. \& Andersen, A.N., 2014, 'Tropical grassy biomes: Misunderstood, neglected, and under threat', Trends in Ecology \& Evolution 29(4), 205-213. https://doi.org/10.1016/j.tree.2014.02.004

Pinto, I., Jack, C. \& Hewitson, B., 2018, 'Process-based model evaluation and projections over southern Africa from coordinated regional climate downscaling experiment and coupled model intercomparison project phase 5 models', International Journal of Climatology 38(11), 4251-4261. https://doi.org/10.1002/joc.5666

Pinto, I., Lennard, C., Tadross, M., Hewitson, B., Dosio, A., Nikulin, G. et al., 2016, 'Evaluation and projections of extreme precipitation over southern Africa from two CORDEX models', Climatic Change 135, 655-668. https://doi.org/10.1007/ s10584-015-1573-1

Purdon, J., Parr, C.L. \& Somers, M.J., 2019, 'Grazing by large savanna herbivores indirectly alters ant diversity and promotes resource monopolisation', PeerJournl 7, e6226. https://doi.org/10.7717/peerj.6226

Redfern, J., Grant, C., Gaylard, A. \& Getz, W., 2005, 'Surface water availability and the management of herbivore distributions in an African savanna ecosystem', Journal of Arid Environments 63(2),406-424. https://doi.org/10.1016/j.jaridenv.2005.03.016

Rogers, K. \& Biggs, H., 1999, 'Integrating indicators, endpoints and value systems in strategic management of the rivers of the Kruger National Park', Freshwater Biology 41(2), 439-451.

Rogers, K.H., 1997, 'Operationalizing ecology under a new paradigm: An African perspective', in S.T.A. Pickett, R.S. Ostfeld, M. Shachak \& G.E. Likens (eds.), The ecological basis for conservation: Heterogeneity, ecosystems, and biodiversity, pp. 60-77, Chapman and Hall, New York, NY.

Rogers, K.H., 2003, 'Adopting a heterogeneity paradigm: Implications for management of protected savannas', in J.T. Du Toit, K.H. Rogers \& H.C. Biggs (eds.), The Kruger experience: Ecology and management of savanna heterogeneity, pp. 41-58, Island Press, Washington, DC.

Rogers, K.H. \& O'Keeffe, J., 2003, 'River heterogeneity: Ecosystem structure, function, and management', in J.T. Du Toit, K.H. Rogers \& H.C. Biggs (eds.), The Kruger experience: Ecology and management of savanna heterogeneity, pp. 189-219, Island Press, Washington, DC.

Rountree, M., Rogers, K. \& Heritage, G., 2000, 'Landscape state change in the semiarid Sabie River, Kruger National Park, in response to flood and drought', South African Geographical Journal 82(3), 173-181. https://doi.org/10.1080/03736245. African Geograph

Sankaran, M., Hanan, N.P., Scholes, R.J, Ratnam, J, Augustine, D.J., Cade, B.S. et al, 2005, 'Determinants of woody cover in African savannas', Nature 438, 846-849. https://doi.org/10.1038/nature04070

Sankaran, M., Ratnam, J. \& Hanan, N., 2008, 'Woody cover in African savannas: The role of resources, fire and herbivory', Global Ecology and Biogeography 17(2), role of resources, fire and herbivory', Global Ecology and Biog

Scheiter, S. \& Higgins, S.I., 2012, 'How many elephants can you fit into a conservation area', Conservation Letters 5(3), 176-185. https://doi.org/10.1111/j.1755-263X.2012.00225.x

Scott, L., 2016, 'Fluctuations of vegetation and climate over the last 75000 years in the Savanna Biome, South Africa: Tswaing Crater and Wonderkrater pollen sequences reviewed', Quaternary Science Reviews 145, 117-133. https://doi. sequences reviewed, Quaternary Scier
org/10.1016/j.quascirev.2016.05.035

Scott, L. \& Lee-Thorp, J.A., 2004, 'Holocene climatic trends and rhythms in southern Africa', in R.W. Battarbee, F. Gasse \& C.E. Stickley (eds.), Past climate variability through Europe and Africa, pp. 69-91, vol. 6., 69-91, Springer, Dordrecht.

Scott, L., Neumann, F.H., Brook, G.A., Bousman, C.B., Norström, E. \& Metwally, A. 2012, 'Terrestrial fossil-pollen evidence of climate change during the last 26 thousand years in Southern Africa', Quaternary Science Reviews 32, 100-118. https://doi.org/10.1016/j.quascirev.2011.11.010

Staver, A.C., Archibald, S. \& Levin, S., 2011, 'Tree cover in sub-Saharan Africa: Rainfal and fire constrain forest and savanna as alternative stable states', Ecology 92(5), 1063-1072. https://doi.org/10.1890/10-1684.1

Staver, A.C. \& Bond, W.J., 2014, 'Is there a "browse trap?" Dynamics of herbivore impacts on trees and grasses in an African savanna', Journal of Ecology 102(3), 595-602. https://doi.org/10.1111/1365-2745.12230

Sundqvist, H.S., Holmgren, K., Fohlmeister, J., Zhang, Q., Matthews, M.B., Spötl, C. \& Körnich, H., 2013, 'Evidence of a large cooling between 1690 and 1740 AD in southern Africa', Scientific Reports 3, 1767. https://doi.org/10.1038/srep01767

Sundstrom, SM., Allen, C.R. \& Gunderson, L., 2016, Resisting resilience theory: a response to Connell and Ghedini', Trends in Ecology \& Evolution 31(6), 412-413. https://doi.org/10.1016/j.tree.2016.03.014 
Van Wilgen, B.W., Govender, N., Smit, I.P. \& MacFadyen, S., 2014, 'The ongoing development of a pragmatic and adaptive fire management policy in a large African savanna protected area', Journal of Environmental Management 132, 358-368. https://doi.org/10.1016/j.jenvman.2013.11.003

Van Wilgen, B.W., Govener, N., Biggs, H.C., Ntsala, D. \& Funda, X.N., 2004, 'Response of savanna fire regimes to changing fire management policies in a large African National Park', Conservation Biology 18(6), 1533-1540. https://doi.org/10.1111/ j.1523-1739.2004.00362.x

Veldman, J.W., Aleman, J.C., Alvarado, S.T., Anderson, T.M., Archibald, S., Bond, W.J. et al., 2019, 'Comment on "The global tree restoration potential"', Science 366(6463), eaay7976. https://doi.org/10.1126/science.aay7976

Venter, Z.S., Hawkins, H.J. \& Cramer, M.D., 2017, 'Implications of historical interactions between herbivory and fire for rangeland management in African savannas', Ecosphere 8(10), e01946. https://doi.org/10.1002/ecs2.1946

Waldram, M., Bond, W.J. \& Stock, W.D., 2007, 'Ecological engineering by a megagrazer: White Rhino impacts on a South African savanna', Ecosystems https://doi. org/10.1007/s10021-007-9109-9
Wigley, B.J., Bond, W.J. \& Hoffman, M.T., 2009, 'Bush encroachment under three contrasting land-use practices in a mesic South African savanna', African Journa of Ecology 47(s1), 62-70. https://doi.org/10.1111/j.1365-2028.2008.01051.x

Wigley, B.J., Bond, W.J. \& Hoffman, M.T., 2010, 'Thicket expansion in a South African savanna under divergent land use: Local vs. global drivers?', Global Change Biology 16(3), 964-976. https://doi.org/10.1111/j.1365-2486.2009.02030.x

Wittemyer, G., Northrup, J.M., Blanc, J., Douglas-Hamilton, I., Omondi, P. \& Burnham, K.P., 2014, 'Illegal killing for ivory drives global decline in African elephants', Proceedings of the National Academy of Sciences 111(36), 13117-13121. https:// doi.org/10.1073/pnas.1403984111

Woodborne, S., Gandiwa, P., Hall, G., Patrut, A. \& Finch, J., 2016, 'A regional stable carbon isotope dendro-climatology from the south African summer rainfall area', PLoS One 11(7), e0159361. https://doi.org/10.1371/journal.pone.0159361

Woodborne, S., Hall, G., Robertson, I., Patrut, A., Rouault, M., Loader, N.J. et al. 2015, 'A 1000-year carbon isotope rainfall proxy record from South African baobab trees (Adansonia digitata L.)', PLOS One 10(5), e0124202. https://doi.org/10.1371/ journal.pone.0124202 


\section{Appendix 1}

TABLE 1-A1: Site locations, ecology and sampling details for sites presented in the article.

\begin{tabular}{|c|c|c|}
\hline Site name (location): Coordinates & Ecology/substrate: Basin size & Core depth/analysis resolution: Date $A D / B C$ \\
\hline 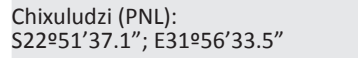 & $\begin{array}{l}\text { Mopane shrubveld/Limpopo palaeofloodplain (recent alluvial soils), } \\
\text { responsive to the Limpopo River: } 100 \text { metres/diameter }\end{array}$ & $80 \mathrm{~cm}$ from surface ( $2 \mathrm{~cm}$ analysis resolution): AD 690-900 \\
\hline $\begin{array}{l}\text { Mahlapanga (KNP): S22 } 53^{\prime} 20.0^{\prime \prime} \text {; } \\
\text { E31 } 02^{\prime} 25.8^{\prime \prime}\end{array}$ & $\begin{array}{l}\text { Mopane-Combretum shrubveld/Granite bedrock and course sand, } \\
\text { tributary to Shingwedzi River: } 50 \text { metres/diameter }\end{array}$ & $\begin{array}{l}80 \mathrm{~cm} \text { from surface ( } 2-8 \mathrm{~cm} \text { analysis resolution): } 3950-3350 \mathrm{BC} \\
\text { with a possible hiatus until } A D 760-890\end{array}$ \\
\hline $\begin{array}{l}\text { Mapimbi lake (KNP): } \mathrm{S} 22^{\circ} 53^{\prime} 20.0^{\prime \prime} \text {; } \\
\text { E31 } 02^{\prime} 25.8^{\prime \prime}\end{array}$ & $\begin{array}{l}\text { Riparian-Mopane shrubveld/Limpopo palaeofloodplain (recent alluvial } \\
\text { soils), responsive to the Limpopo River: } 75 \text { metres/diameter }\end{array}$ & $80 \mathrm{~cm}$ from surface ( $2 \mathrm{~cm}$ analysis resolution): AD 1300 \\
\hline $\begin{array}{l}\text { Radio (PNL): } \\
\text { S2330'40.3"; E3218'09.2" }\end{array}$ & Mopane shrubveld/Deep sandy soil: 50 metres/diameter & $80 \mathrm{~cm}$ from surface ( $2 \mathrm{~cm}$ analysis resolution): AD 1287-1394 \\
\hline
\end{tabular}

PNL, Limpopo National Park; KNP, Kruger National Park. 